DOI https://doi.org/10.30525/978-9934-588-81-5-2.14

\title{
TERMS FORMATION PROCESS INVESTIGATION AND IQ LEVEL ASSESSMENT IN THE UKRANIAN STUDENTS DEPENDENTLY ON THEIR LEADING EXTREMITY
}

\author{
Tkachenko O. V. \\ Candidate of Medical Sciences, \\ Assistant at the Physiology Department \\ Ukrainian Medical Stomatological Academy \\ Sokolenko V. M. \\ Candidate of Biological Sciences, \\ Associate Professor at the Physiology Department \\ Ukrainian Medical Stomatological Academy \\ Morgun Z. K. \\ Candidate of Biological Sciences, \\ Associate Professor at the Physiology department \\ Ukrainian Medical Stomatological Academy \\ Fedotenkova N. M. \\ Assistant at the Physiology Department \\ Ukrainian Medical Stomatological Academy

\section{Goujili $\mathbf{O}$.} \\ 4th year Student at the Dental Faculty \\ Ukrainian Medical Stomatological Academy \\ Poltava, Ukraine
}

Intellect represents the ability [1, p. 1-672]: to be adapted to the new situation at conscious level, to acquire knowledge, to use the acquired knowledge and skills in daily and professional life. With other words it represents integrity of all human cognitive processes. It is known that there are different approaches to intellect nature analysis in psychology and psychophysiology: of structure, of functioning ways, of measurement.

It is worthy to say about intellect as a biological formation with psychophysiological analysis positions. It testifies that individual varieties in intellectual development indexes are explained by [2, p. 1-400; 3, p. 1-272]: physiological factors row influence, genotype.

There are three aspects of intellect (by G. Eysenck, 1995): 
1) Biological intellect. It represents a genetically determined biological basement of cognitive functioning and all its individual varieties. It deals to cortex activity directly occurring on the basement of neuro-physiological and biochemical factors.

2) Psychometric intellect [4, p. 1-512; 5, p. 1-171]. It is assessed by intellect tests and depends on: biological intellect, social-cultural factors.

3) Social intellect. It represents intellectual abilities expressing in everyday life. It depends upon: psycho-metric intellect, personal peculiarities, study, social-economical status.

Sometimes biological intellect is designated as intellect A, social one as intellect B. It is evidently that the B one is wider than the A one and comprises it. J.Piaget discovered a sensory-motor intellect development theory according to which sensory-motor intellect develops in a child from childhood to 2 years [6, p. 1-384].

The abbreviature IQ is used for two terms designation: intellect coefficient applying only to children, on one hand, and the intellectualism coefficient as a mere of the adult mental abilities on the other hand. There are two facts which are opposite to each other: from one point of view, the intellectual tests have no any restricted scientific background and, from another one, the intellect testing gives useful practical results.

Our investigation aim: To assess some cognitive abilities in the Ukrainian students dependently on their asymmetry individual profile. The investigation tasks: 1) To assess the students asymmetry individual profile (classification to dexters, real sinisters, hidden sinisters, unreal sinisters and ambidexters). 2) To analyze the students' marks, participation in different activity types (scientific, artistic, social). 3) To analyze the students' IQ by Eysenck dependently on asymmetry individual profile. 4) To investigate terms formation process in the investigated group dependently on asymmetry individual profile.

The investigative methods: We have used following methodics for asymmetry individual profile assessment [7, p. 1-374]: dominant extremity, dominant finger, dominant eye, dominant leg, Napoleon's pose, probe with applauding, anamnesis (sinisters among close relatives, arms and hemispheres traumas - for asymmetry individual profile assessment). We have analyzed the students' marks, participation in different activity types (scientific, artistic, social). Also we have proposed them to solve tests compiled by H.J.Eysenck (for IQ assessment) [8, p. 1-288].

\section{We have investigated terms formation process:}

Experiment 1 - terms determining - the investigated person is proposed a row of words indicating different terms (for example, «table», «tractor», 
«tree» et al.) and is proposed to determine them. Experiment 2 - terms comparison and difference - the investigated person is proposed the terms pairs which he must compare or find common features having designated them with one word (for instance, «a chair and a sofa is a furniture»). Experiment 3 - logic correlations finding out - the investigated person is proposed the changings from alternatives (for example, high-thick, lowthin, fat-hungry et al.); to find opposite characteristics (warm...., low...., weak....). Experiment 4 - subject imaginations classification $\left(4^{\text {th }}\right.$ one is excessive), subjects free classification. The investigated person is proposed 4 subject images (for example: «spade», «saw», «axe», «log») and to find the one subject inappropriate to the rest ones and to explain his choice having designated 3 chosen figures with one word or the investigated person is proposed a row of subjects (or their images) and he should classify these subjects after their division into several groups. The essence of these subjects (experiments) is that the investigated person must understand the conditionality of this operation and to find the principle of subjects' generalization.

The investigation results:

Table 1

IQ level by Eysenck testing in the Ukranian students $(n=81)$ dependently on their leading extremity

\begin{tabular}{|c|c|c|c|c|c|}
\hline & $\begin{array}{c}\text { Dexters, } \\
\mathbf{n = 1 0}\end{array}$ & $\begin{array}{c}\text { Real } \\
\text { sinisters, } \\
\mathbf{n = 1 0}\end{array}$ & $\begin{array}{c}\text { Hidden } \\
\text { sinisters, } \\
\mathbf{n = 2 7}\end{array}$ & $\begin{array}{c}\text { Unreal } \\
\text { sinisters, } \\
\mathbf{n = 2 7}\end{array}$ & $\begin{array}{c}\text { Ambidexters, } \\
\mathbf{n = 7}\end{array}$ \\
\hline $\begin{array}{c}\text { IQ, } \\
\text { degrees }\end{array}$ & $50-70$ & $90-100$ & $80-90$ & $75-82$ & $90-100$ \\
\hline
\end{tabular}

The results have demonstrated that real sinisters (with sinistrality among parents) and ambidexters were more able in different branches of life and their activity was more differentiated and united bigger types. The real sinisters and ambidexters IQ level has been fluctuated from 90 till 100 degrees. Hidden (forced) sinisters IQ level was 80-90 degrees. Unreal sinisters IQ was 75-82 degrees. Dexters IQ in the investigated group was 50-70 degrees. Though it should be mentioned that tests with time limit have been solved with big difficulties by sinisters comparatively to the dexters (that can be used in a study process, to our point of view).

The results interpreting: 7-10 degrees - very easy to be performed; 5-7 degrees - easy to be performed; 3-4 - difficult to be realized; 1-2 - practically impossible to be realized. 
Table 2

Terms formation process investigation in the Ukranian students $(n=81)$ dependently on their leading extremity

\begin{tabular}{|c|c|c|c|c|c|}
\hline Operation & $\begin{array}{c}\text { Dexters, } \\
\mathbf{n = 1 0}\end{array}$ & $\begin{array}{c}\text { Real } \\
\text { sinisters, } \\
\mathbf{n = 1 0}\end{array}$ & $\begin{array}{c}\text { Hidden } \\
\text { sinisters, } \\
\mathbf{n = 2 7}\end{array}$ & $\begin{array}{c}\text { Unreal } \\
\text { sinisters, } \\
\mathbf{n = 2 7}\end{array}$ & $\begin{array}{c}\text { Ambidexters, } \\
\mathbf{n = 7}\end{array}$ \\
\hline $\begin{array}{c}\text { Terms } \\
\text { determining }\end{array}$ & 5 & 7 & 7 & 5 & $9-10$ \\
\hline $\begin{array}{c}\text { Terms } \\
\text { comparison } \\
\text { and } \\
\text { difference }\end{array}$ & $8-10$ & $2-4$ & $2-4$ & $6-7$ & $6-7$ \\
\hline $\begin{array}{c}\text { Logic } \\
\text { correlations } \\
\text { finding out }\end{array}$ & $9-10$ & $1-4$ & $1-4$ & $5-6$ & $7-9$ \\
\hline $\begin{array}{c}\text { Subjects free } \\
\text { classification }\end{array}$ & 4 & $9-10$ & $9-10$ & 3 & 8 \\
\hline
\end{tabular}

The data given in the table 2 tell that terms determining was easier for ambidexters, then for real and hidden sinisters and (more difficult) for dexters and unreal sinisters. Terms comparison and difference was the easiest for dexters, then for ambidexters and unreal sinisters and difficult for sinisters (both real and hidden). Logic correlations finding out was easy for dexters and ambidexters, at average level - for unreal sinisters while difficult to be realized or practically impossible to be made - for real and hidden sinisters. Subjects free classification making was an easy operation for real and hidden sinisters, ambidexters, difficult for dexters and unreal sinisters (they study proposed classifications easier than created the new ones by free way). The results received, probably, can be explained by following. Left hemisphere dominant in dexters and unreal sinisters is logic one, performs consequent operations easier, thinking type for left hemisphere is a successive one. Right hemisphere dominant in real and hidden sinisters is alogic, creative one, it performs semantic operations better and thinking type for it is simultant (id est the sinister "captures» the information as a whole and it is rather difficult for him to tell about details that is easy, in turn, to the dexters and moreover to ambidexters).

The results can be recommended to be used while individual works compiling for the geniuses taking into account their interhemispherical asymmetry profile as well at classes for differentiated approach to the students. 


\section{References:}

1. Столяренко Л.Д. Основы психологии. Ростов н/Д, 2003. 672 с.

2. Марютина Т.М., Ермолаев О.Ю. Введение в психофизиологию. Москва, 2002. 400 с.

3. Практический интеллект / Р.Дж. Стернберг, Дж.Б. Форсайт, Дж.Хедланд, Дж.А. Хорвард и др. Спб: Питер, 2002. 272 с.

4. Елисеев О.П. Практикум по психологии личности. СПб: Питер, 2008. 512 c.

5. Айзенк Г.Ю. Проверьте свои интеллектуальные способности. Рига: Виеда. 1992. 171 с.

6. Пальчик А.Б.Эволюционная неврология. СПб: Питер, 2002. $384 \mathrm{c}$.

7. Лурия А.Р. Основы нейропсихологии. М.: Наука, 1975. 374 с.

8. Батаршев А.В. Диагностика черт личности и акцентуаций: Практическое руководство. М. : Психотерапия, 2006. 288 с.

DOI https://doi.org/10.30525/978-9934-588-81-5-2.15

\section{ЗНАЧЕННЯ ВИВЧЕННЯ ВНУТРІШНІХ ХВОРОБ У ФАХОВІЙ ПІДГОТОВЦІ ЛІКАРЯ}

Третяк Н. Г.

кандидат медичних наук, доиент кафедри внутрішньої медицини № 1

Українська медична стоматологічна академія

Штомпель В. Ю.

кандидат медичних наук, викладач

Полтавський базовий медичний коледж

Кудря І. П.

кандидат медичних наук, асистент кафедри внутрішньої медицини № 1 Украӥнська медична стоматологічна академія

Шапошник О. А.

кандидат медичних наук, доиент кафедри внутрішньої медищини № 1 Украӥнська медична стоматологічна академія м. Полтава, Украӥна

Особливу роль у формуванні світогляду лікаря будь-якого фаху відіграє вивчення внутрішніх хвороб, оскільки узагальнює клінічні 